Article

\title{
Community Participation in the Decision-Making Process for Sustainable Tourism Development in Rural Areas of Hong Kong, China
}

\author{
Bonnie K. L. Mak ${ }^{1}$, Lewis T. O. Cheung ${ }^{2, *}$ (D) and Dennis L. H. Hui ${ }^{2}$ \\ 1 Department of Geography, The University of Hong Kong, Hong Kong, China; kwunling@connect.hku.hk \\ 2 Department of Social Sciences, The Education University of Hong Kong, Hong Kong, China; \\ huilh@eduhk.hk \\ * Correspondence: ltocheung@eduhk.hk; Tel.: +852-2948-8908; Fax: +852-2948-8018
}

Received: 10 August 2017; Accepted: 19 September 2017; Published: 22 September 2017

\begin{abstract}
Examining the extent to which a community plays a role in the decision-making process in tourism planning can provide a better understanding of how tourism can benefit a community. Arnstein's ladder of citizen participation (ALCP) has been adopted by tourism scholars to understand both the nature of the participation expected of the community and the community's actual participation in tourism development. However, the literature on tourism development and community involvement is underdeveloped in the context of urban tourism, and few studies have attempted to identify the differences between the expected and actual participation of local residents. Identifying this gap reveals the reasons behind it and generates possible suggestions and solutions. The level of community participation of Tai $\mathrm{O}$ residents has been assessed by employing Arnstein's framework. The results indicated the difference between the level of local residents' expected and actual participation in tourism development. The reasons for the difference are identified, and suggestions for improvement are provided.
\end{abstract}

Keywords: Arnstein; citizen participation level; tourism planning; community participation; sustainable tourism development; Hong Kong

\section{Introduction}

Incorporating local communities' opinions in tourism planning and development is a vital element of sustainable tourism [1]. Notably, community participation (CP) is essential for sustainable tourism development, as tourism has a close relationship with the livelihood of the local community [2,3] and the tourism destinations are communities with which local residents interact [4]. CP is an important strategy to improve tourism development $[5,6]$. Tourism planning is likely to be supported by the local community if the local residents have been invited to participate in the decision-making process. Their understanding of the potential benefits can motivate their participation [7] which can also develop a more democratic community $[8,9]$. To understand potential benefits that could be bought by tourism development to a community, it is important to examine the extent to which local residents are thoroughly informed and invited to join in the tourism-planning process. A number of tourism scholars have adopted various frameworks to understand the level of participation and power distribution within communities and to determine whether the frameworks can be applied to both developed and developing countries [10]. For example, Aref and Redzuan [10] attempted to establish a typology of $\mathrm{CP}$ in tourism development based on scholarly typologies of participation that do not directly address tourism. In addition, Muganda [11] applied Tosun [12] normative typologies of CP in his research, and Okazaki [13] reviewed the principal theories used to discuss CP, including the "ladder of citizen participation", power redistribution, collaboration processes, and social capital creation. 
These theories form the basis of defining a community-based tourism (CBT) model. Wang et al. [14] applied Tosun's normative typologies of $\mathrm{CP}$ in their research; they explained the survey results using Tosun's model and quoted Tosun's explanation of the limits of CP in developing countries, especially in the centralisation of public administration. Certain tourism scholars have adopted the framework of Arnstein's ladder of citizen participation (ALCP) to understand the expected and actual participation of the local community when involved in the decision-making process of tourism development $[10,13]$.

However, limited studies thus far have attempted to measure the level of citizens' actual and expected participation in public consultation and compare the two concepts [15]. The measurement of expectations at the level of CP in tourism development enables an understanding of people's desired forms of $\mathrm{CP}$, but this information alone cannot identify the barriers that might prevent communities from participating. As Tosun [12] suggested, in addition to political culture, a wide range of factors might influence the level of participation, such as sociodemographic characteristics, limited educational opportunities to engage local people in tourism development, and longevity of $\mathrm{CP}$. An examination of actual participation in tourism development provides information about the status quo, but whether the situation meets the community's expectations remains unknown. Identifying the gap between the two helps us to examine the reasons for the gap and generates possible suggestions and solutions. Such findings can be important to the sustainable tourism development of a rural community. The framework of ALCP is adopted to assess the expected and actual level of CP of the local community in tourism development and to identify the gap between the two. Possible determinants of the gap are also identified. The findings of this study are important because they offer a holistic view of local residents' expected and actual participation in a decision-making process for tourism development. Such information can be essential for the government to evaluate the effectiveness of its approach to $\mathrm{CP}$ processes.

\section{Community Participation (CP) in Sustainable Tourism Development}

Community participation $(\mathrm{CP})$ is an important strategy for sustainable tourism development in rural communities [16]. Scholars have not come to a conclusion on the meaning of the term because different wordings have been used interchangeably. The definition of $\mathrm{CP}$ adopted for this study is based on Tosun's proposed definition [17]: " $\mathrm{CP}$ is a categorical term that legitimises various forms (direct, indirect, active, passive, etc.) of participation at different levels (local, regional, and national) under specific circumstances" [16]. CP has been adopted as a strategy to improve development and conservation projects $[5,18]$. Through $\mathrm{CP}$, tourism development incorporates the opinions of the local community, which can help to fulfil their expectations [7,19]. The local community will be more supportive of tourism development if they have a chance to participate in the planning and development process [7] and to help create a more democratic community [8,9]. However, a lack of interest in or knowledge of tourism development can be a major barrier to the success of $\mathrm{CP}$ in rural areas [20-22].

A ladder of citizen participation proposed by Arnstein (1969) addresses the degree of power distribution in terms of a typology of citizen participation that includes eight rungs (manipulation, therapy, informing, consultation, placation, partnership, delegated power, and citizen control) [16] that are further categorised into top, middle, and bottom levels of participation (Figure 1). The bottom rungs of the ladder, (1) manipulation and (2) therapy, represent levels of nonparticipation because the authority holds the real power to avoid allowing local community participation in decision-making about development. The middle rungs of the ladder, (3) informing, (4) consultation, and (5) placation, describe levels of tokenism that allow the local community to know and offer opinions on projects. It is not ensured that their views will be taken into consideration in the decision-making process. The top rungs of the ladder are (6) partnership, (7) delegated power, and (8) citizen control [16]. Real participation begins where negotiation between various stakeholders is included and the local community takes up part of the responsibility for decision-making. At levels 7 and 8, participants' 
views have been taken into consideration in the decision-making arena, and they are empowered to make decisions about development.

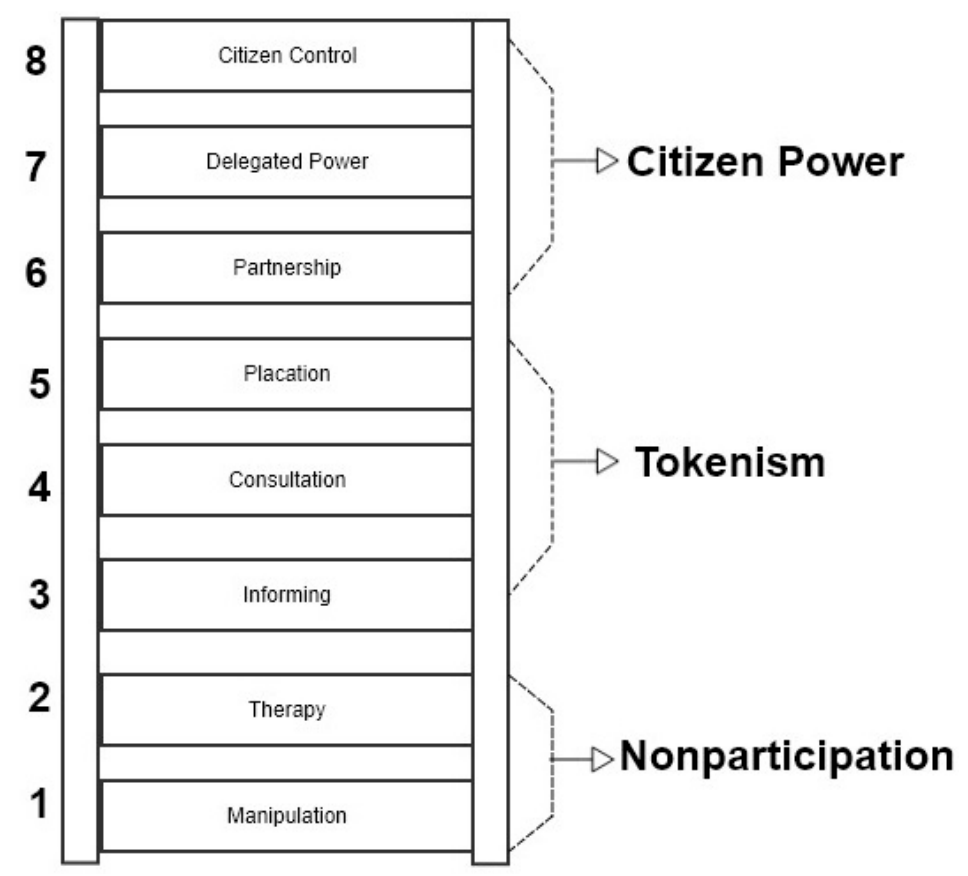

Figure 1. Arnstein's (1969) Ladder of Citizen Participation (ALCP).

\section{Methods}

\subsection{Study Area}

The study area, Tai $\mathrm{O}$, is located on the western coast of Lantau Island, the largest island of Hong Kong. It is a small fishing village with a number of residents who commute to urban areas for job opportunities on weekdays and return to Tai $\mathrm{O}$ on weekends. A well-developed public transportation system on Lantau Island has gradually dissolved the boundary between rural and urban areas. The Tai O development has drawn public attention, as the government has proposed to implement a revised concept plan for Lantau Island, and Tai $\mathrm{O}$ will be heavily influenced by the plan. The Lantau development project has been an important one in Hong Kong, as the proposal has been highlighted in Policy Addresses in recent years [23-31]. The Tai $\mathrm{O}$ fishing village has come onto the stage because it has been identified in the plan for rural and cultural tourism opportunities as part of ecotourism development in rural Lantau. [30]. Therefore, a series of public consultation activities were organised by the government in 2007 and 2008 to collect views from the local community on the plan. These activities offered an opportunity for researchers to study the effectiveness of public engagement in the decision-making process of the Tai $\mathrm{O}$ tourism development project.

In the early 20th century, Tai $\mathrm{O}$ was one of the largest fishing villages on the western coast of Hong Kong, with a population of more than 10,000. From 1981 to 2006, its population declined from 5150 to 2951 [32]. The Tai O population is mainly Chinese (94.7\%) with more female (54.5\%) than male (45.5\%), and the population is dominated by residents aged over 65 years due to the influence of rural-urban migration in past decades. A majority of the younger generation moved to the city for work and study. This has led Tai $\mathrm{O}$ to become an aged community with over one-third of the population aged over 65 years, compared with only $12.4 \%$ of the population of Hong Kong [33]. 


\subsection{Research Design}

To understand the expected and actual levels of $\mathrm{CP}$ by Tai $\mathrm{O}$ residents, a questionnaire survey was administered in Tai O. Those who resided in Tai O prior to 21 March 2009 and who were aged eighteen or over were invited to complete the questionnaire. The level of actual participation in tourism-related projects by those who were informed and participated in the public forums could then be examined. Thus, a purposive sampling method was employed. Purposive sampling is a type of nonprobability sampling technique that relies on the judgment of the researcher in selecting the units (e.g., people, cases/organizations, events, and data items) to be studied. Usually, the sample being investigated is quite small, especially when compared to probability sampling techniques [34]. Since the total population of Tai $\mathrm{O}$ was approximately 2250 , we therefore set a target to obtain approximately 400 responses to achieve a $95 \%$ confidence interval that ensured the representativeness of the sample.

The socio-demographic composition of the respondents largely aligned with the 2011 by-census data of the Tai O community, produced by the Census and Statistics Department [33], to ensure that the gender and age of the respondents were consistent with the population of Tai $\mathrm{O}$.

\subsection{Questionnaire Design}

There are two independent variables and numerous dependent variables in the study. The two independent variables are expected citizen participation (ECP) and actual citizen participation (ACP) in the tourism-related decision-making process, while the numerous dependent variables include sociodemographic factors, such as gender, educational level, income level, etc. ECP and ACP could not be measured with the same set of criteria; therefore, two different sets of criteria were developed. Local residents' ECP in the decision-making process was separated into many elements, and a number of scales were used by the researchers to measure this variable [10-12].

The questionnaire was divided into two main sections (Table 1). The first section had 4 subparts to determine the extent to which the respondents perceived themselves as representatives of their fellow community residents. The first 3 subparts addressed the respondents' own perception of themselves as representatives of the other residents: whether they received demands and requests from other residents for aid, felt influential and essential in the organisation to which they belonged, and felt influential in the organisation's programming. Each question referred to the characteristics of different rungs of ALCP. Each question was measured on a five-point Likert scale ranging from $1=$ strongly disagree to $5=$ strongly agree. The last subpart was designed to seek the respondents' views of their engagement in the decision-making process for the Tai O tourism development; a yes-or-no response and a qualitative response were recorded. All the questions were designed based on the previous literature $[11,12]$ and were modified to fit the local context.

The second section of the questionnaire contained 4 questions to determine the respondents' actual participation in and awareness of the 1st and 2nd public forums organised by the government and to determine how the respondents had obtained information about the public forums.

Quantitative data from the onsite questionnaire, together with the qualitative data collected through open-ended responses, were evaluated to determine which rung of ALCP the Tai O case achieved.

The validity of question items in the questionnaire was examined by a panel of experts, and a pilot survey was conducted [35]. The panel of experts, which consisted of a representative of a non-governmental social services organisation in the study area, a leader of the Tai $\mathrm{O}$ rural committee, and three professors, had sufficient knowledge on the study area and could provide valuable comments on the question items in terms of the language used and the appropriateness of the content. The questionnaire was translated into Chinese for the survey, and the Chinese version was reviewed by three native Chinese speakers to improve the wording and avoid ambiguity. Then, a pilot survey with local residents was done to ensure that the prospective respondents understood the wording of the question items [36]. The respondents of the pilot survey were asked to review the questions on 
whether they fully reflected the situation in Tai O. The final questionnaire survey was conducted after revision of the questionnaire according to the comments of various parties.

Table 1. Question items in the questionnaire for the onsite survey.

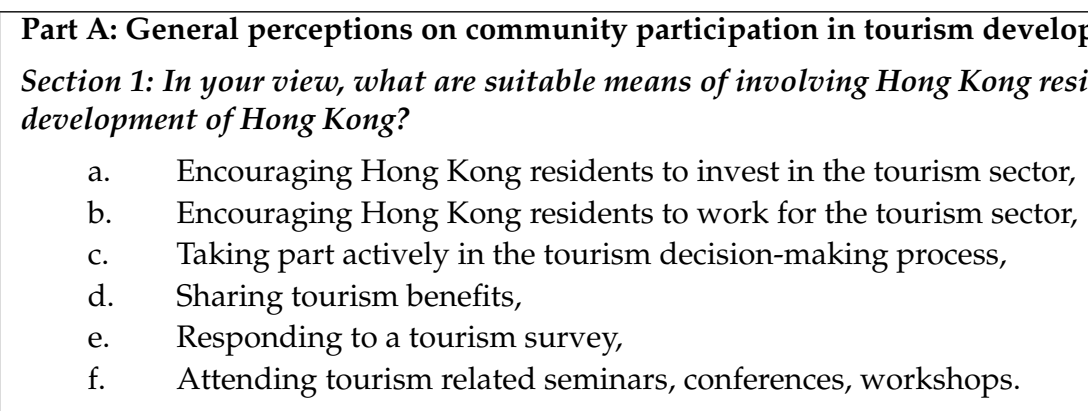

Section 2: In your opinion, what should be an appropriate role of Tai $O$ residents in the tourism development of Tai $\mathrm{O}$ ?
a. Tai $\mathrm{O}$ residents should take the leading role as entrepreneurs (e.g., the owner of a hostel) (top rungs of the ladder),
b. Tai O residents should take the leading role as workers at all levels (top rungs of the ladder),
c. Tai $\mathrm{O}$ residents should have a voice in the decision-making process of local tourism development (top rungs of the ladder),
d. Tai $\mathrm{O}$ residents should be consulted when tourism policies are being made (middle rungs of the ladder),
e. Tai $\mathrm{O}$ residents should be consulted, but the final decision on tourism development should be made by formal bodies (middle rungs of the ladder),
f. Tai $\mathrm{O}$ residents should not participate by any means (bottom rungs of the ladder),
g. Tai $\mathrm{O}$ residents should be financially supported to invest in tourism development (bottom rungs of the ladder).

Section 3: Who should make decisions on tourism development in Tai O?

1. Government departments (e.g., Civil Engineering and Development Depart., CEDD) (bottom rungs of the ladder),

2. Regional administrative units (e.g., Island District Council) (bottom rungs of the ladder),

3. Local administrative units (e.g., Tai O Rural Committee) (bottom rungs of the ladder),

4. Government departments and Local administrative units in consultation with Tai $\mathrm{O}$ residents (middle rungs of the ladder),

5. A tourism development committee formed by Tai $\mathrm{O}$ residents (top rungs of the ladder),

6. Market forces,

7. Others, please specify:

Section 4: Do you feel personally involved in the decision-making process regarding the tourism development of Tai $\mathrm{O}$ (e.g., public forums)?

Part B: The Public forums

1. Did you hear about and/or attend the 1st public forum about the improvement works for the Tai O facelift?

2. How did you obtain the information about the 1st public forum?

3. Did you hear about and/or attend the 2 nd public forum about the improvement works for the Tai O facelift?

4. How did you obtain the information about the 2nd public forum?

\section{Results and Discussion}

\subsection{Profile of Survey Respondents}

Of the 483 Tai $\mathrm{O}$ residents who were approached, 360 agreed to complete the questionnaire; 351 completed questionnaires were received, yielding a response rate of $72.7 \%$. The chi-square test was done to compare the socio-economic characteristics of the respondents and the Tai O population. 
The results indicated no significant difference at $p<0.05$ between the gender and age group distribution of the sample and census data, indicating that the sample was sufficiently representative of the Tai $O$ community (Table 2).

Table 2. Comparison of the socio-economic characteristics of respondents with the 2011 census data of Hong Kong.

\begin{tabular}{|c|c|c|c|c|}
\hline \multicolumn{2}{|c|}{ Socioeconomic Variables } & \multirow{3}{*}{$\begin{array}{c}\begin{array}{c}\text { Respondents } \\
\text { (\%) }\end{array} \\
51.3 \\
48.7 \\
\end{array}$} & \multirow{3}{*}{$\begin{array}{c}\begin{array}{c}2011 \text { Census (\%) } \\
\text { (C\&SD, 2012) }\end{array} \\
51.2 \\
48.8\end{array}$} & \multirow{3}{*}{$\begin{array}{c}\begin{array}{c}\text { Chi-Square Test } \\
(p \text {-Value })\end{array} \\
0.984\end{array}$} \\
\hline \multirow{2}{*}{ Gender } & Male & & & \\
\hline & Female & & & \\
\hline \multirow{5}{*}{ Age group } & $18-24$ & 7.2 & 8.2 & \multirow{5}{*}{0.994} \\
\hline & $25-34$ & 9.5 & 10.1 & \\
\hline & $35-44$ & 16.7 & 16.8 & \\
\hline & $45-54$ & 15.9 & 16.1 & \\
\hline & 55 or above & 50.7 & 48.8 & \\
\hline \multirow{5}{*}{ Education Level } & Primary or below & 63.4 & 29.1 & \multirow{5}{*}{0.000} \\
\hline & Lower secondary & 7.9 & 18.6 & \\
\hline & Upper secondary & 12.7 & 27.6 & \\
\hline & Post-secondary & 2.4 & 8.2 & \\
\hline & Undergraduate & 9.8 & 16.6 & \\
\hline \multirow{11}{*}{ Annual income $(\mathrm{HK} \$)$} & Under 2000 & 4.0 & 2.3 & \multirow{11}{*}{0.017} \\
\hline & 2000-3999 & 3.4 & 8.5 & \\
\hline & $4000-5999$ & 6.5 & 13.5 & \\
\hline & $6000-7999$ & 10.8 & 15.1 & \\
\hline & 8000-9999 & 5.2 & 11.7 & \\
\hline & $10,000-14,999$ & 10.2 & 17.9 & \\
\hline & $15,000-19,999$ & 2.5 & 8.0 & \\
\hline & $20,000-24,999$ & 2.2 & 3.3 & \\
\hline & $25,000-39,999$ & 0.9 & 2.4 & \\
\hline & 40,000 and over & 1.5 & 2.5 & \\
\hline & $\begin{array}{l}\text { N.A (People not in } \\
\text { working population) }\end{array}$ & 50.0 & 50.0 & \\
\hline
\end{tabular}

The gender of the respondents was evenly distributed, with $51.3 \%(n=180)$ male and $48.7 \%(n=171)$ female. In terms of age, over $50 \%$ of the respondents were aged 55 or over, followed by $16.7 \%$ aged 35 to 44 , indicating that the elderly are dominant in number in Tai O. Only approximately $16 \%$ of the respondents were less than 34 years old. The respondents' education level was low compared with the general population of Hong Kong in 2011. More than $30 \%$ of Tai O residents never received a formal education, and over $23 \%$ had only completed primary-level education. Moreover, nearly one-third of the respondents were retired, reflecting that Tai $\mathrm{O}$ is an aging community.

\subsection{Expectation of Citizen Participation (ECP)}

The component of $\mathrm{CP}$ expected by Tai $\mathrm{O}$ residents has four dimensions: residents' views on participation in development process, the role of local residents in tourism development, who should be in charge of decision making for tourism development, and other appropriate aspects of this process.

Aref and Redzuan [10] noted that participation is a dynamic process that is difficult to predict or quantify using a standard assessment method; they suggest that it originates from and is moulded by individuals' experiences with participation. Some researchers, such as Taal [37], have tried to quantify levels of participation. Taal [37] suggested that such quantification can be misleading because it does not reflect the whole participation process and it is difficult to fit into each category of participation. Therefore, instead of quantifying the level of citizen participation, this study employs the ALCP framework (Figure 1) as a basis to make this evaluation. The framework characterises levels of public involvement, ranging from the ideal of citizen control to a state of creeping manipulation by officials and powerful interest groups. 
In terms of the ECP, the Tai $\mathrm{O}$ residents were asked to indicate their agreement with a series of statements in relation to a suitable means of participation in tourism development, the role residents should play in this development, and who should be in charge of making decisions (Table 3 ). The residents' answers were examined based on the mean $(M)$ scores of each variable from the lowest to the highest. For Hong Kong society as a whole, the residents suggested that the people of Hong Kong should participate in the tourism decision-making process $(M=3.92)$, even though they placed the priority of expected participation in tourism development strongly on economic benefits, including job opportunities in the tourism sector $(M=4.11)$, sharing tourism benefits $(M=4.10)$, and investment opportunities in the tourism sector $(M=4.03)$. Similarly, Liu and Cheung [38] found that local residents who operated tourism-related businesses believed that tourism development in Tai O could enhance economic development. Local indigenous people are more likely to engage in tourism planning and the development process in Tai O [32].

Table 3. Respondents' Views on Suitable Means of Involving Hong Kong Citizens in Tourism Development in Hong Kong $(n=351)$.

\begin{tabular}{|c|c|c|c|c|c|c|c|}
\hline Statements & $M^{\mathrm{a}}$ & SD & $\begin{array}{c}\text { SD } \\
\%\end{array}$ & $\begin{array}{l}\mathrm{D} \\
\%\end{array}$ & $\begin{array}{l}\mathbf{N} \\
\%\end{array}$ & $\begin{array}{l}\mathrm{A} \\
\%\end{array}$ & $\begin{array}{c}\text { SA } \\
\%\end{array}$ \\
\hline Encouraging local people to work for the tourism sector & 4.11 & 0.75 & 0.9 & 2.0 & 11.7 & 56.1 & 29.3 \\
\hline Sharing tourism benefits & 4.10 & 0.79 & 0.9 & 3.1 & 12.0 & 53.6 & 30.5 \\
\hline Encouraging local people to invest in the tourism sector & 4.03 & 0.89 & 1.4 & 5.7 & 12.8 & 48.7 & 31.3 \\
\hline Taking part actively in tourism decision-making process & 3.92 & 0.77 & 1.1 & 3.7 & 16.2 & 59.8 & 19.1 \\
\hline Responding to a tourism survey & 3.84 & 0.78 & 0.9 & 4.9 & 20.1 & 57.9 & 16.3 \\
\hline Attending tourism-related seminars, conferences, and workshops & 3.64 & 0.84 & 2.6 & 6.0 & 25.3 & 56.6 & 9.5 \\
\hline
\end{tabular}

Notes: $\mathrm{SD}=$ strongly disagree, $\mathrm{D}=$ disagree, $\mathrm{N}=$ neutral, $\mathrm{A}=$ agree, $\mathrm{SA}=$ strongly agree, ${ }^{\text {a }}$ The Mean $(M)$ score of the question items.

Interestingly, for the statements that related specifically to Tai $\mathrm{O}$, the respondents gave higher scores to political forms of participation than to economic ones (Table 4). They showed strong support for the view that they should be consulted before tourism policies were made $(M=4.37)$. When respondents were asked to rank which party was best qualified to make decisions (Table 5), nearly half chose "government departments and local administrative units in consultation with Tai O residents" (45.5\%), followed by "government departments" (14.7\%), "others" (14.7\%), "a tourism development committee formed by Tai O residents" (11.8), "market forces" (6.6\%), "local administrative units" (5.2\%), and "regional administrative units" (1.4\%). The respondents suggested that local residents' views should be considered so that their views could be refereed and reflected in the decision-making process. Over $79 \%$ of the respondents $(M=4.13)$ agreed that local residents should have financial support to invest in the tourism industry. Their agreement with this statement reflects some major characteristics of partnership, the sixth rung of the ALCP and the lowest rung of the citizen power level. Partnership can be the most effective approach when an organised group exists in the community and the leader of that group is held accountable for decision-making. The local community has financial resources that allow them to pay their leaders and to establish his or her team to oversee the whole development. These components may signify that the desired level of participation by local residents is at the partnership rung of ALCP.

The respondents did not agree that the level of citizen participation reached the topmost rungs on $\mathrm{ALCP}$, as they indicated that they have limited knowledge of $\mathrm{CP}$ and the decision-making process, which may be because the majority of respondents were older and had a low education level. Although most agreed or strongly agreed with the statement that residents should participate actively in the decision-making process of tourism development, they expressed that they did not have any right or power to contribute to the decision-making process and had insufficient knowledge to make such a decision. Their views imply that the local residents do not understand the concept of $\mathrm{CP}$ and are not aware that participation in the decision-making process is important for the sustainable development of their community. 
Table 4. Respondents' Views on Tai O Residents' Roles in Tourism Development in Tai O $(n=351)$.

\begin{tabular}{|c|c|c|c|c|c|c|c|}
\hline Statements & $M^{\mathrm{a}}$ & SD & $\begin{array}{l}\text { SD } \\
\%\end{array}$ & $\begin{array}{l}\mathrm{D} \\
\%\end{array}$ & $\begin{array}{l}\mathbf{N} \\
\%\end{array}$ & $\begin{array}{l}\mathrm{A} \\
\%\end{array}$ & $\begin{array}{l}\text { SA } \\
\%\end{array}$ \\
\hline $\begin{array}{l}\text { Tai } O \text { residents should be consulted when } \\
\text { tourism policies are being made }\end{array}$ & 4.37 & 0.69 & 0 & 0.9 & 9.4 & 42.0 & 47.7 \\
\hline $\begin{array}{l}\text { Tai O residents should have a voice in the } \\
\text { decision-making process of local tourism } \\
\text { development }\end{array}$ & 4.29 & 0.75 & 1.1 & 1.1 & 7.7 & 47.6 & 42.5 \\
\hline $\begin{array}{l}\text { Tai O residents should take the leading role } \\
\text { as entrepreneurs (e.g., the owner of a hostel) }\end{array}$ & 4.15 & 0.88 & 0.6 & 5.7 & 11.7 & 42.2 & 39.9 \\
\hline $\begin{array}{l}\text { Tai } O \text { residents should take the leading role } \\
\text { as workers at all levels }\end{array}$ & 4.13 & 0.73 & 0 & 2.8 & 12.5 & 53.8 & 30.8 \\
\hline $\begin{array}{l}\text { Tai O residents should be financially } \\
\text { supported to invest in tourism development }\end{array}$ & 4.13 & 0.95 & 1.7 & 5.2 & 13.2 & 38.5 & 41.4 \\
\hline $\begin{array}{l}\text { Tai O residents should be consulted but the } \\
\text { final decision on tourism development } \\
\text { should be made by formal bodies }\end{array}$ & 3.16 & 1.22 & 11.7 & 20.6 & 20.0 & 35.7 & 12.0 \\
\hline $\begin{array}{l}\text { Tai O residents should not participate by } \\
\text { any means }\end{array}$ & 1.75 & 0.86 & 45.3 & 40.5 & 9.7 & 3.1 & 1.4 \\
\hline
\end{tabular}

a The Mean $(M)$ score of the question items.

Table 5. Residents' Views on Who Should Make Decisions on Tourism Development in Tai O ( $n=347)$.

\begin{tabular}{lcc}
\hline \multicolumn{1}{c}{ Options } & $n$ & $\%$ \\
\hline Government departments and local administrative units in consultation with Tai O residents & 158 & 45.5 \\
Government departments (e.g., Civil Engineering and Development Dept., CEDD) & 51 & 14.7 \\
Others & 51 & 14.7 \\
A tourism development committee formed by Tai O residents & 41 & 11.8 \\
Market forces & 23 & 6.6 \\
Local administrative units (e.g., Tai O Rural Committee) & 18 & 5.2 \\
Regional administrative units (e.g., Island District Council) & 5 & 1.4 \\
Total & 347 & 100.0 \\
\hline
\end{tabular}

Due to the characteristics of the population, Tai O residents did not show confidence in taking full responsibility for tourism development in Tai O. They believed that decisions should be made by the government and relevant administrative units by taking their views and opinions into consideration. There are a number of reasons why the majority of the respondents did not suggest that the tourism development committee should be composed solely of local residents. Most respondents believed that local residents held different opinions on tourism development and most were only concerned with their self-interest, particularly those with relevant businesses. They did not believe that the local residents were equipped with sufficient ability to implement a tourism development plan. Therefore, great assistance from the government is an appropriate approach to make a tourism development project successful [38]. Second, they felt powerless to establish a committee with all members selected from the local community, given the high level of illiterate residents and aging population [39]. Third, there is a lack of residents with a relevant tourism background who could form a capable committee. Fourth, the respondents had little knowledge on how to establish such a committee. Fifth, the respondents were suspicious about whether they would be empowered by the government to be in full responsibility of Tai O's development [3,32,40]. Sixth, some respondents were skeptical that they would obtain sufficient financial and technical support to take initiative to implement a development plan through a self-constructed tourism development committee. However, they did not want the decision to be made solely by the government because they had the general impression that some government officials ignored their needs and did not safeguard the interests of the local 
community. They preferred that the government participate in decision-making because they believed that abundant resources such as human capital, financial support, and technical assistance could be gained if relevant governmental units were involved in the decision-making process [32,41]. Most respondents believed that the multi-stakeholder approach, which is a common approach in sustainable tourism development where different stakeholders are participating in the decision-making process, should be adopted in the case of Tai $\mathrm{O}$, even though the local residents may have limited knowledge on this concept.

The discussion above suggests that the level of $\mathrm{CP}$ expected by Tai $\mathrm{O}$ residents in tourism development falls on the sixth and lowest rung-partnership—of the citizen power level of ALCP [42] (Figure 1), as the local residents indicated their willingness to take part in the decision-making process, and their desire to be empowered to participate in the decision-making process and to make appropriate decisions through effective negotiation with authorities. This aligns with the characteristics of rung six of the ALCP [43]. However, the population's structure, low levels of education, and lack of tourism knowledge are barriers preventing them from reaching the highest rungs of ALCP.

\subsection{Actual Citizen Participation (ACP) of Local Residents}

The results of the questionnaire survey revealed that the majority of the respondents $(68.7 \%, n=241)$ did not consider themselves to be involved in the decision-making process for tourism development (Table 6). The reasons given can be categorised into two aspects: thirteen are categorised into personal aspects, and the other three fall under the public aspect. The most common personal reasons for the local residents to not participate in the decision-making process were a lack of availability $(27 \%, n=65)$, old age $(18.3 \%, n=44)$, and being unclear about their role. 'Criticisms of public participation activities in the past' ranked fourth among all and included the following: inadequate opportunities were provided for residents to take part in such processes; residents were not invited to attend public consultation activities; there was limited opportunity for residents to voice their views in public forums; and insufficient public forums were provided to allow them to participate in the decision-making process. The criticism "residents were not invited to attend public consultation activities" is consistent with the results regarding the respondents' awareness of and attendance at the two public forums (Table 7). More than one-quarter of the respondents had not been aware of and had not participated in the public forums (1st: $32.3 \%, n=112 ; 2$ nd: $24.8 \%, n=86$ ). Five local residents believed that they were not welcomed by the government to participate $(2.1 \%)$, and two believed that the decision-making process was monopolised by the Tai O Rural Committee $(0.8 \%)$; that is, that local residents lacked influential power in the decision (Table 6). The reason for this perception may be that the majority of the residents were not interested in participating in the decision-making process because they thought that they were too old and unqualified for the process. Moreover, the workforce in Tai O is busy at work and do not want to spend time participating in this process. Third, the members of the Tai O Rural Committee were in charge of the whole decision-making process and discouraged local residents from engaging in it. The findings suggest that personal conditions are a prominent factor in shaping citizens' participation in Tai O and might inhibit CBT participation [39].

Although Tai O residents were willing to be counted into the decision-making process for tourism development, the actual participation level was still low, and their actual participation placed on the fourth rung of ALCP. The local community had low participation in public consultation activities because it was not well informed about these activities and because of the timing of these activities (Figure 1). Our questionnaire survey results reported that the local residents were less aware of the public forums and their participation in these consultation activities was low. Lack of awareness and the inconvenient schedule of the activities are two main reasons for this low attendance. Most respondents (over $40 \%$ ) obtained information on the public forum through two channels: the bulletin boards of the Tai O Rural Committee and the Islands District Office, and banners in the Tai O Car Park. Approximately one-third of respondents obtained the information through personal networks, implying that the public forums were not well promoted by the government to encourage participation. 
Apart from the publicity of the public forums and scheduling, Tai O experiences structural barriers to successful $\mathrm{CP}$ as a result of the characteristics of the population (aging population and a high illiteracy rate).

Table 6. Respondents' Reasons for Not Feeling Personally Involved in the Process of Decision-Making on Tourism Development in Tai O.

\begin{tabular}{|c|c|c|c|}
\hline Categories & Themes & $n$ & $\%$ \\
\hline Personal & Not available & 65 & 27.0 \\
\hline Personal & Old age & 44 & 18.3 \\
\hline Personal & $\begin{array}{l}\text { Tai } O \text { residents were uncertain about their role of participating in the } \\
\text { decision-making process }\end{array}$ & 35 & 14.5 \\
\hline Public & Criticisms about the past public participation activities & 32 & 13.3 \\
\hline Personal & Education background & 21 & 8.7 \\
\hline Personal & Interest & 12 & 5.0 \\
\hline Personal & Awareness of the public participation activities & 7 & 2.9 \\
\hline Personal & Understanding about community participation & 6 & 2.5 \\
\hline Public & Criticisms about the HKSAR Government & 5 & 2.1 \\
\hline Personal & Irrelevant answers & 4 & 1.7 \\
\hline Personal & Financial problem & 2 & 0.8 \\
\hline Personal & Understanding about Tai $\mathrm{O}$ & 2 & 0.8 \\
\hline Personal & Economic activity status & 2 & 0.8 \\
\hline Public & $\begin{array}{l}\text { Tai O residents' lack of influential impact on the decision-making } \\
\text { process due to monopolisation of power by Tai O Rural Committee }\end{array}$ & 2 & 0.8 \\
\hline Personal & Ethnicity & 1 & 0.4 \\
\hline Personal & Obligation & 1 & 0.4 \\
\hline Total & & 241 & 100.0 \\
\hline
\end{tabular}

Table 7. Respondents' Ways of Obtaining the Information about the 1st and 2nd Public Forums $(n=235,261)$.

\begin{tabular}{|c|c|c|c|c|c|}
\hline Ways & $\begin{array}{c}1 \text { st } \\
n\end{array}$ & $\begin{array}{c}2 \text { nd } \\
n\end{array}$ & $\begin{array}{c}1 \text { st } \\
\%\end{array}$ & $\begin{array}{l}2 \text { 2nd } \\
\%\end{array}$ & $\begin{array}{c}\% \\
\text { Change }\end{array}$ \\
\hline Invitation letter and/or e-mail from Tai O Rural Committee & 7 & 8 & 2.98 & 3.07 & +0.09 \\
\hline $\begin{array}{l}\text { The website of Civil Engineering and Development } \\
\text { Dept.-'Revitalisation for Tai O' }\end{array}$ & 7 & 11 & 2.97 & 4.21 & +1.24 \\
\hline $\begin{array}{l}\text { Advertisements posted in public areas (i.e., the bulletin board of } \\
\text { Tai O Rural Committee, the bulletin board of Islands District } \\
\text { Office, banners in Tai O Car Park) }\end{array}$ & 96 & 109 & 40.85 & 41.76 & +0.91 \\
\hline Personal networks (e.g., family members, friends and neighbours) & 88 & 94 & 37.45 & 36.02 & -1.43 \\
\hline Others & 37 & 39 & 15.74 & 14.94 & -0.8 \\
\hline Total & 235 & 261 & 100 & 100 & 11.06 \\
\hline
\end{tabular}

Regardless of the effectiveness of public forums, Tai O residents have been given a chance to learn more about the project and voice their views. However, the government offered no assurance to take their views into account in the decision-making process. This situation offers evidence why their current actual participation level placed on the fourth rung of ALCP. The government's low transparency with regard to the public consultation process led to distrust among residents that their community interests were not safeguarded during the decision-making process. They were afraid that 
decisions were made in favour of powerful interest groups, such as well-established tour operators, multinational companies, and influential individuals in the community.

According to the results of the questionnaire survey, we can place Tai $\mathrm{O}$ residents' actual participation level on the fourth rung (consultation) of the tokenism level on ALCP (Figure 1). A high level of citizen participation was not achieved in the case of the Tai O development project. Organising public forums could become a standard procedure for the government in Tai O development projects. The government could therefore claim that they have gleaned community opinions before making decisions and received empowerment from the local community for their decision.

\section{Implications and Conclusions}

$\mathrm{CP}$ is regarded as an important process to achieve sustainable tourism development. However, limited studies have been done to evaluate the level of CP in tourism development and to explore the differences between local residents' expected and actual participation in public consultation activities. In our study, the theoretical framework of ALCP has been employed to assess local residents' level of $\mathrm{CP}$ and compare their expected and actual participation in tourism development projects in their community. The findings of this study can be an important reference for the relevant government departments and developers, because the gap between local residents' expected and actual participation highlighted the limitations of approaches that have been adopted by the government in the public consultation process. The findings revealed that strategies for promoting public participation activities were not effective and should be improved in order to reach out to different stakeholders. In addition, the gaps found between the residents' expected and actual involvement in the decision-making process suggested that there were shortfalls in the public consultation process; in particular, local residents were not well informed about the public consultation activities and the schedules were not convenient for them.

To enhance the level of $\mathrm{CP}$ in making decisions on developments, a number of measures can be taken by the relevant government departments. More effective strategies in promoting public consultation activities should be adopted. For instance, the promotion period of public consultation forums should be extended so that local residents can be well informed in advance, which should boost the attendance rate. The selection of dates for the public consultation forums should be better arranged to cater to the schedules of local residents. In addition, comprehensive information on the proposed projects should be offered to the local residents to enhance their understanding of a project in order to encourage and motivate them to participate in the forums and actively express their views. Besides this, workshops to introduce the project can be arranged before the public forums in order to enhance relevant knowledge in the community, so that the participants of public forums can ask precise questions and offer concrete comments.

ALCP [42] proved to be a useful framework to assess the level of $\mathrm{CP}$ in the decision-making process for tourism development. Our study has demonstrated the adoption of the theoretical framework to assess the level of $\mathrm{CP}$ in rural areas of Hong Kong. Future research could adopt a similar method to investigate the level of $\mathrm{CP}$ in various development projects, which could help facilitate the sustainable development of a community.

Acknowledgments: The authors are grateful to the Start-Up Research Grant for providing funding support for this research project (Grant number HKIEd RG72/2014-2015R).

Author Contributions: Bonnie K. L. Mak carried out the field work, analyzed the data and drafted the manuscript; Lewis T. O. Cheung analyzed the field data and drafted the manuscript; and Dennis L. H. Hui drafted the manuscript.

Conflicts of Interest: The authors declare no conflict of interest. 


\section{References}

1. The Global Development Research Center (GDRC). Charter for Sustainable Tourism. Available online: http:/ / www.gdrc.org/uem/eco-tour/charter.html (accessed on 10 December 2013).

2. Scheyvens, R. Ecotourism and the empowerment of local communities. Tour. Manag. 1999, 20, $245-249$. [CrossRef]

3. Hossen, M.A. Participatory mapping for community empowerment. Asian Geogr. 2016, 33, 97-113. [CrossRef]

4. Blank, U. The Community Tourism Industry Imperative: The Necessity, the Opportunities, It's Potential; Venture: Stage College, PA, USA, 1989.

5. Pearce, P.L.; Moscardo, G.; Ross, G.F. Tourism Community Relationships, 1st ed.; Pergamon: New York, NY, USA, 1996; p. 259.

6. Saufi, A.; O'Brien, D.; Wilkins, H. Inhibitors to host community participation in sustainable tourism development in developing countries. J. Sustain. Tour. 2014, 22, 801-820. [CrossRef]

7. Inskeep, E. National and regional tourism planning. In National and Regional Tourism Planning: Methodologies and Case Studies; Routledge: London, UK, 1994; pp. i-ix.

8. Simmons, D.G. Community participation in tourism planning. Tour. Manag. 1994, 15, 98-108. [CrossRef]

9. Syme, G.J.; Macpherson, D.K.; Seligman, C. Factors motivating community participation in regional water-allocation planning: A test of an expectancy-value model. Environ. Plan. A 1991, 23, 1779-1795. [CrossRef]

10. Aref, F; Redzuan, M.R. Assessing the level of community participation as a component of community capacity building for tourism development. Eur. J. Soc. Sci. 2009, 8, 68-75.

11. Muganda, M. Community Involvement and Participation in Tourism Development in Tanzania: A Case Study of Local Communities in Barabarani Village, Mto wa Mbu, Arusha-Tanzania; Victoria University of Wellington: Wellington, New Zealand, 2009.

12. Tosun, C. Expected nature of community participation in tourism development. Tour. Manag. 2006, 27, 493-504. [CrossRef]

13. Okazaki, E. A community-based tourism model: Its conception and use. J. Sustain. Tour. 2008, 16, 511-529. [CrossRef]

14. Wang, H.; Yang, Z.; Chen, L.; Yang, J.; Li, R. Minority community participation in tourism: A case of Kanas Tuva villages in Xinjiang, China. Tour. Manag. 2010, 31, 759-764. [CrossRef]

15. Prouty, C.; Koenig, E.S.; Wells, E.C.; Zarger, R.K.; Zhang, Q. Rapid assessment framework for modeling stakeholder involvement in infrastructure development. Sustain. Cities Soc. 2017, 29, 130-138. [CrossRef]

16. Mak, K.L. Community Participation in Tourism: A Case Study from Tai O; The University of Hong Kong: Hong Kong, China, 2012.

17. Tosun, C. Stages in the emergence of a participatory tourism development approach in the developing world. Geoforum 2005, 36, 333-352. [CrossRef]

18. Lee, A.K.-Y. The role of private sector in built heritage conservation: A case study of Xinhepu, Guangzhou. Asian Geogr. 2016, 33, 115-139. [CrossRef]

19. Tosun, C.; Jenkins, C.L. The evolution of tourism planning in third-world countries: A critique. Prog. Tour. Hosp. Res. 1998, 4, 101-114. [CrossRef]

20. Tosun, C. Limits to community participation in the tourism development process in developing countries. Tour. Manag. 2000, 21, 613-633. [CrossRef]

21. Campbell, L.M. Ecotourism in rural developing communities. Ann. Tour. Res. 1999, 26, 534-553. [CrossRef]

22. Gartner, W.C. Tourism Development: Principles, Processes, and Policies; Van Nostrand Reinhold: New York, NY, USA, 1996.

23. Office of the Chief Executive. The 2005 Policy Address: Policy Agenda; Office of the Chief Executive: Hong Kong, China, 2005.

24. Office of the Chief Executive. The 2005-06 Policy Address: Policy Agenda; Office of the Chief Executive: Hong Kong, China, 2005.

25. Office of the Chief Executive. The 2006-07 Policy Address: Policy Agenda; Office of the Chief Executive: Hong Kong, China, 2006.

26. Office of the Chief Executive. The 2007-08 Policy Address: Policy Agenda; Office of the Chief Executive: Hong Kong, China, 2007. 
27. Office of the Chief Executive. The 2008-09 Policy Address: Policy Agenda; Office of the Chief Executive: Hong Kong, China, 2008.

28. Office of the Chief Executive. The 2009-10 Policy Address: Policy Agenda; Office of the Chief Executive: Hong Kong, China, 2009.

29. Lantau Development Task Force. Concept Plan for Lantau; Lantau Development Task Force: Hong Kong, China, 2004.

30. Lantau Development Task Force. Revised Concept Plan for Lantau; Lantau Development Task Force: Hong Kong, China, 2007.

31. Office of the Chief Executive. The 2013 Policy Address; Office of the Chief Executive: Hong Kong, China, 2013.

32. Liu, S.; Cheng, I.; Cheung, L. The roles of formal and informal institutions in small tourism business development in rural areas of South China. Sustainability 2017, 9, 1194. [CrossRef]

33. Census and Statistics Department. 2012 Population by-Census: Basic Tables for Tertiary Planning Units; Census and Statistics Department: Hong Kong, China, 2013.

34. Calmorin, E.A. Research Methods and Thesis Writing; Rex Bookstore, Inc.: Manila, Philippines, 2007.

35. Dimanche, F. Cross-cultural tourism marketing research: An assessment and recommendations for future studies. In Global Tourist Behavior; Uysal, M., Ed.; Haworth: New York, NY, USA, 1994; pp. 123-160.

36. Finn, M.; Elliott-White, M.; Walton, M. Tourism and Leisure Research Methods: Data Collection, Analysis, and Interpretation; Longman: Harlow, UK, 2000.

37. Taal, H. Decentralization and Community Participation for Improving Access to Basic Services: An Empirical Approach; Innocenti Occasional Papers, Economic Policy Series, No. 35; UNICEF International Child Development Centre: Florence, Italy, 1993.

38. Liu, S.; Cheung, L.T.O. Sense of place and tourism business development. Tour. Geogr. 2016, 18, $174-193$. [CrossRef]

39. Jaafar, M.; Rasoolimanesh, S.M.; Ismail, S. Perceived sociocultural impacts of tourism and community participation: A case study of Langkawi Island. Tour. Hosp. Res. 2015, 17, 123-134. [CrossRef]

40. Lo, A.Y.; Cheung, L.T.O.; Lee, A.K.-Y.; Xu, B. Confidence and trust in public institution natural hazards management: Case studies in urban and rural China. Prof. Geogr. 2016, 68, 475-484. [CrossRef]

41. Nunkoo, R. Tourism development and trust in local government. Tour. Manag. 2015, 46, 623-634. [CrossRef]

42. Arnstein, S.R. A ladder of citizen participation. J. Am. Inst. Plan. 1969, 35, 216-224. [CrossRef]

43. Swapan, M.S.H. Who participates and who doesn't? Adapting community participation model for developing countries. Cities 2016, 53, 70-77. [CrossRef] 